\title{
The influence of the passive evaporative cooling vest on a chemical industry workers and physiological strain level in hot conditions
}

\author{
Radovan M. Karkalic ${ }^{1}$, Dalibor B. Jovanovic ${ }^{2}$, Sonja S. Radakovic ${ }^{3}$, Dusan S. Rajic ${ }^{4}$, Biljana V. Petrovic ${ }^{5}$, \\ Negovan D. Ivankovic ${ }^{1}$, Zeljko B. Senic ${ }^{6}$ \\ ${ }^{1}$ University of Defense, Military Academy, Belgrade, Serbia \\ ${ }^{2}$ Technical Test Center, General staff of the SAF, Serbia \\ ${ }^{3}$ Medical Faculty of the Military Medical Academy, University of Defense, Belgrade, Serbia \\ ${ }^{4}$ University of Belgrade, Innovation Center, Faculty of Technology and Metallurgy, Belgrade, Serbia \\ ${ }^{5}$ Faculty of science, University of Kragujevac, Kragujevac, Serbia \\ ${ }^{6}$ Military Technical Institute, Belgrade, Serbia
}

\begin{abstract}
The present study was conducted in order to evaluate efficiency of a personal body cooling system based on passive evaporative technologies and its effects on test subjects and their psycho-physiological suitability during exertional heat stress in hot environment. Performed results are based on conducted tests in climatic chamber in the Military Medical Academy Institute of Hygiene in Belgrade. Ten male test subjects were subjected to exertional heat stress test consisted of walking on motorized treadmill at a speed of $5 \mathrm{~km} / \mathrm{h}$ in hot environment. Tests were performed with and without cooling system. As a physiological strain indicator the following parameters have been determined: mean skin temperature, tympanic temperature, heart rate and sweat rate. Results confirmed that cooling vest worn over the clothes was able to attenuate the physiological strain levels during exercise, when compared to identical exposure without the cooling system.
\end{abstract}

Keywords: chemical industry, heat stress, cooling vest, working uniform, physiological strain.

Available online at the Journal website: http://www.ache.org.rs/HI/

\section{PROFFESIONAL PAPER}

UDC 614.873:66

Hem. Ind. 69 (6) 587-594 (2015)

doi: 10.2298/HEMIND140705079
Thermal insulation of clothing systems mainly depends on the physical activity and the ambiental conditions (temperature and relative humidity). The amount of heat produced by humans depends on the physical activity and can differ from $100 \mathrm{~W}$ while resting to over $1000 \mathrm{~W}$ during maximum physical performance. At extreme activity, which is often a case with winter sports, the body temperature rises with enhanced heat production. To maintain this increase within a certain limit, the body perspires in order to dissipate thermal energy from the body by evaporative cooling. If the thermal insulation of the clothing is decreased during physical activity, a part of the generated heat can be removed by convection, thus the body doesn't have to perspire so much.

The quality of insulation in a garment in terms of heat and cold will be widely managed by the thickness and density of its component fabrics. High thickness and low density make insulation better. It is observed in many cases that thermal insulation is offered by air gaps between the garment layers. However, the external temperature also influences the effectiveness of the insulation. The more extreme the temperature, be it

Correspondence: R.M. Karkalic, University of Defense, Military Academy, Pavla Jurisica Sturma 33, 11000 Belgrade, Serbia.

E-mail: rkarkalic@yahoo.com

Paper received: 5 July, 2014

Paper accepted: 22 October, 2014 very high or very low, the less effective the insulation becomes. Thus, a garment designed for its capability to protect against heat or cold is chosen by its wearer on the expectation of the climate in which the garment is to be worn [1].

The accumulation of heat, reflecting the peripheral and body core temperature, occurs during heavy physical exertion or exposure to warm and humid environment. Long-term accumulation of heat in a quantity of about $0.5 \mathrm{~W} / \mathrm{kg}$ during 1 to $2 \mathrm{~h}$, leads to an increase in body temperature that some people are unable to tolerate. Heat stress can occur in compensated and uncompensated form. Compensed heat stress (CHS) occurs when the heat loss is in balance with its production, so that it can reach the core equilibrium temperature at a given physical activity. It is usually present in most of the activities related to the implementation of dedicated military tasks. Uncompensated heat stress occurs when demands for disclosure of heat (sweat evaporation) overcome the evaporative capacity of the environment. During uncompensed heat stress (UCHS), the body cannot achieve steady state core temperature, so it rises until it reaches physiological limits. Heat exhaustion in terms UCHS occurs at a relatively low internal temperature. Due to inadequate cooling (due to lack of evaporation of sweat) skin temperature remains high. Bloodstream is relocated to expanded vascular in order to remove the heat from inside the body, which 
reduces the minute volume and increases frequency of heart. UCHS extremely reduces physical performance, so that these conditions demand special regimes of work and rest cycles, with the use of active cooling during breaks [2].

Ability to compensate heat stress is primarily determined by biophysical factors (environmental conditions, clothing, the intensity of physical exertion), and moderately by the influence of biological condition (acclimatization to heat and hydration) [3].

Physiological thermoregulation involves activation of mechanism for disclosure of the excess heat and increase blood flow through the skin, which is achieved by enhancing heart rate and simultaneous increasing of sweating [4]. During physical activity in hot conditions, sweat rate raising from 1 to $1,5 \mathrm{l} / \mathrm{h}$ is not unusual, and may even reach a value of $2 \mathrm{l} / \mathrm{h}$ under extreme efforts, providing a potential loss of excess heat by evaporation of $4500 \mathrm{~kJ}$, or $1 \mathrm{~kW}(14 \mathrm{~W} / \mathrm{kg}$ for a person whose body weight is $70 \mathrm{~kg}$ ). In the absence of adequate rehydration, this process leads to loss of body fluids from all body compartments, including the vascular component. Dehydration causes an increase of body core temperature and cardiovascular strain. For each percent of weight lost, the core temperature additionally raises by 0.15 to $0.2{ }^{\circ} \mathrm{C}$, while heart rate increases by 5 bpm [5].

In long periods of exposure to a hot environment the major mechanism for dissipating heat is sweat evaporation, which is proportional to the effective (exposed) skin area, the water vapor pressure gradient between the skin and the environment, and the water vapor permeability of the clothing. Hence, when protective military clothing is worn, sweat evaporation rates decrease and heat dissipation is reduced [6]. The efficiency of physiological adaptation depends on the heat amount generated in the active muscles, the intensity of the carried external work as well as the level of biophysical heat exchange with environment [7].

Contemporary needs of chemical industry personnel request the best possible physiological suitability and comfort while working in hot conditions (Fig. 1). With this in mind, different systems for body cooling have been developed, with a main purpose to increase comfort as well as to reduce thermal stress. Cooling system industrial application has many other significant valid benefits, such as increased work duration, decrease in hydration needs, improved mental acuity and maintains physical performance of the workers. Although many systems exist today, they generally can be classified in the several basic groups: evaporative cooling products, products based on phase change materials (PCM), liquid circulation systems, compressed air systems and thermoelectric systems [8].

The focus of this study was to investigate the efficiency of the cooling vest based on evaporative principle, combined with working uniform, on physiological suitability during physical effort in hot environment. We hypothesized that vest wearing will alleviate the physiological strain of test subjects and increase ability of industrial personnel to successfully complete any job in extremely hot conditions.

\section{EXPERIMENTAL METHODS AND PROCEDURES}

\section{Subjects}

The participants involved in examination were 10 male test subjects $(27.2 \pm 2.6$ years), with similar anthropometric parameters $(74 \pm 7 \mathrm{~kg}, 184 \pm 9 \mathrm{~cm})$. Before exercises started, the subjects were briefed on the nature of the experiment, its purpose, conditions, safety measures and potential medical risks. Each participant read and signed an informed consent form, in accordance to standards of medical safety during examination in extreme hot or cold environment [9]. The protocol for the investigation was approved by competent ethical committee. The procedures performed in the present study corresponded to the standards of thermal strain evaluation by psychological measurements [10].

Performed results are based on exertional heat stress tests (EHST) conducted in climatic chamber in the Military Medical Academy, Institute of Hygiene, Belgrade, Serbia.
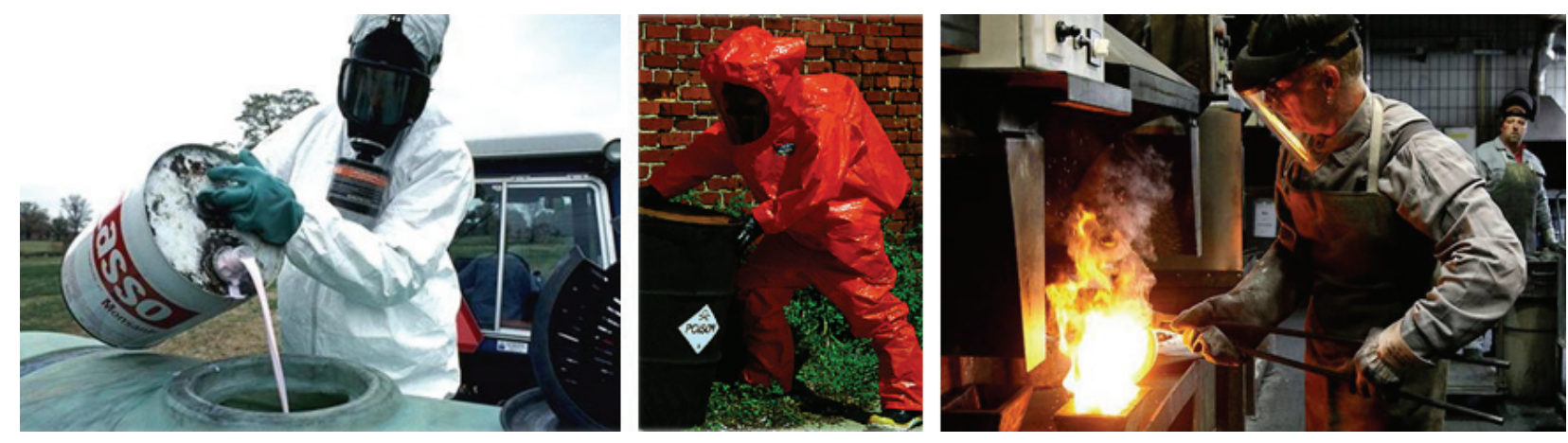

Figure 1. Workers exposed to heat stress in chemical industry process. 


\section{Body cooling system}

The Arctic Heat ${ }^{\circledR}$ cooling system (Fig. 2) tested in this study belongs to the passive evaporative cooling systems. Passive evaporative systems utilize the heat absorbed from the wearer's body to evaporate water that is stored in a gel or specially developed crystals. The gel or crystals are built into a garment that allows the water vapor to be released into the surrounding air. By initial soaking in water (activation), crystals swell into gel form, which has ability to keep constant temperature for a long time.

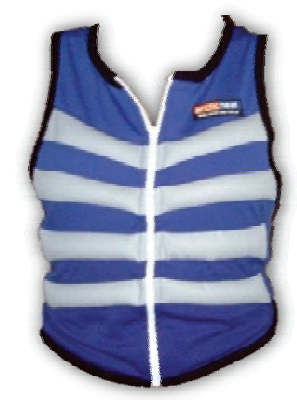

Figure 2. Arctic Heat personal cooling vest.

Preparation process comprised the following simple steps: initially soaking in water for $15 \mathrm{~min}$, removing, grabbing top and bottom of vest and gently twisting in opposite directions to remove excess water, then finally hanging to dry. For the cooling effects, vest has to be placed in freezer. Active working time depends of the preparation. If frozen for $2 \mathrm{~h}$ or longer it will stay cold up to $2 \mathrm{~h}$. The longer period vest placed in the freezer, the longer it will stay cold. Vest weights $800 \mathrm{~g}$ to $1 \mathrm{~kg}$ (when correctly activated).

\section{Experimental protocol}

Each subject performed two tests, both times wearing working uniform, with and without cooling vest over. In both cases, exercises performed under the same climatic conditions (temperature $40{ }^{\circ} \mathrm{C}$, relative humidity $58 \%$, air speed $<0.3 \mathrm{~m} / \mathrm{s}$ ). Before each test conducted, it was necessary to prepare climatic cham- ber, treadmill, measurement devices and other equipment. Working uniform consists of textile material (67\% cotton, 33\% polyester and rip-stop construction). Climatic chamber started minimum one hour before, in order to achieve projected temperature. Each subject was weighed without any equipment, before and after every experiment.

Taking in consideration climatic conditions, each test was initially limited on maximum $45 \mathrm{~min}$. Criteria for termination before the maximal time were: achieving critical value of the tympanic temperature $\left(39^{\circ} \mathrm{C}\right)$, or heart rate (190 beats per min), or participant's subjective feeling of unbearable effort.

All temperature measurements from the subjects during every exposure were automatically monitored and recorded in real-time using a physiological data monitoring system (Biopac Systems, Inc. USA) [12,13]. System consists of MP150 acquisition unit, universal interface module (UIM100C) and five skin temperature amplifier modules (SKT 100C), single channel, differential amplifier designed especially for skin and core temperature monitoring (Fig. 3).

The UIM100C Universal Interface Module (2) is the interface between the MP150/100 and external devices. Typically, the UIM $100 \mathrm{C}$ is used to input pre-amplified signals (usually greater than \pm 0.1 volt peak-peak) and/or digital signals to the MP150/100 acquisition unit. Other signals (e.g. those from electrodes or transducers) connect to various signal-conditioning modules.

The Universal Interface Module (UIM100C) is designed to serve as a general-purpose interface to most types of laboratory equipment. The UIM100C consists of sixteen $3.5 \mathrm{~mm}$ mini-phone jack connectors for analog inputs, two $3.5 \mathrm{~mm}$ mini-phone jack connectors for analog outputs, and screw terminals for the 16 digital lines, external trigger, and supply voltages.

The SKT100C skin temperature amplifier module is a single channel, differential amplifier designed especially for skin and core temperature and respiration flow (rate) monitoring. The SKT100C is designed for general temperature measurement, respiration rate determination, psycho-physiological investigations and sleep studies [11].
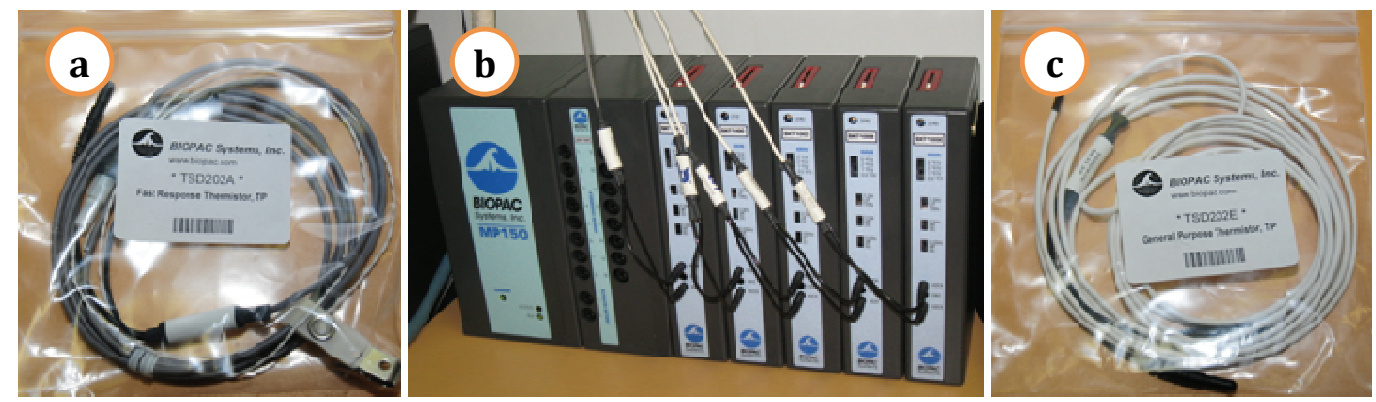

Figure 3. Physiological data monitoring system MP150 BIOPAC: MP150/100 Acquisition unit, UIM100C Universal interface module and Skin temperature amplifier modules SKT 100C (a); thermistor transdusers TSD202A (b) and TSD202E (c). 
The SKT100C employs any of the BIOPAC TSD202 series thermistor transducers (Fig. 3) to measure temperature. The SKT100C includes a lower frequency response selection switch that permits either absolute (DC) or relative (via a 0.05 high-pass filter) temperature measurements [12].

Heart rate was measured and recorded automatically using a Quinton ${ }^{\circledR}$ Q4500 Exercise Test Monitor (Quinton Instruments Company, USA). Continual monitoring was done using monitors that received readings from the heart rate straps that were fastened to each subject (on the chest and bottom of spine). The same device was used for control and handling with treadmill (speed and grade).

\section{Measurement of tympanic temperature}

Method used in this study aims to mesuring the tempeature of the tympanic membrane $\left(T_{\mathrm{ty}}\right)$ whose vascularisation is provided in part by the internal carotid artery, which also supplies the hypothalamus. As the thermal inertia of the eardrum is very low, due to its low mass and high vascularity, its temperature reflects the variations in arterial blood temperature, which influence the centers of thermoregulations [10].

Tympanic temperature was measured by conducting thermo-element TSD202A into the aural channel and investing as close as possible to the eardrum. This measurement was continually, with recording data every $10 \mathrm{~s}$.

\section{Measurement of skin temperature}

Skin temperature $\left(T_{\text {sk }}\right)$ varies widely over the surface of the body, especially during extreme ambiental conditions. Skin temperature is influenced by:

- the thermal exchanges by conduction, convection, radiation and evaporation at the surface of the skin, and

- the variations of skin blood flow and of the temperature of the arterial blood reaching the particular part of the body [10].

In warm and hot enviroment, exept in the precence of the high asymetrial radiation, local skin temperatures tend to be homogeneous, so few measuring points can be used with accuracy [10]. In this study case, the mean body skin temperature $\left(T_{s k}\right)$ was determined continually, mesuring of local body temperatures on four points, using transdusers types TSD202E and TS202F.

Skin temperature varies widely over the surface of the body and especially when the ambient conditions are cold. Skin temperature is influenced by:

- the thermal exchanges by conduction, convection, radiation and evaporation at the surface of the skin and
- the variations of skin blood flow and of the temperature of the arterial blood reaching the particular part of the body.

Mean skin temperature $\left(T_{\text {sk }}\right)$ is obtained from the following formula:

$T_{\text {sk }}=0.28 T_{\text {sk } 1}+0.28 T_{\text {sk } 2}+0.16 T_{\text {sk } 3}+0.28 T_{\text {sk } 4}$

where: $T_{\text {sk } 1}$ - skin temperature measured in the middle of the neck root, $T_{\text {sk2 }}-$ skin temperature measured in the middle of the right scapula, $T_{\mathrm{sk} 3}$ - skin temperature measured in the middle of the upper palm side, $T_{\text {sk } 4}$ skin temperature measured in the middle of right shin.

\section{Assessment of thermal strain on the basis of heart rate}

Heart rate $(H R)$ over a time interval $t$ (in $\min$ ) is defined as $H R=n / t$, where $n$ is the number of heartbeats observed during this time interval. It is expressed in beats per min (bpm) [10].

At any given time, the heart rate can be considered as the sum of several components, which are not independent of each other:

$H R=H R_{0}+\Delta H R_{\mathrm{M}}+\Delta H R_{\mathrm{S}}+\Delta H R_{\mathrm{T}}+\Delta H R_{\mathrm{N}}+\Delta H R_{\varepsilon}$

In the context of this study, only the increase in heart rate connected with the thermal strain experienced by the subject $\left(\Delta H R_{\mathrm{T}}\right)$, was examined. The other components represent:

- limit of heart rate $\left(H R_{0}\right)$,

- increase in heart rate linked with work metabolism $\left(\Delta H R_{\mathrm{M}}\right)$,

- increase in heart rate linked with static exertion $\left(\Delta H R_{\mathrm{S}}\right)$

- increase in heart rate due to psychological factors $\left(\Delta H R_{\mathrm{N}}\right)$,

- residual component in heart rate $\left(\Delta H R_{\varepsilon}\right)$.

\section{Assessment of physiological strain on the basis of body-mass loss due to sweating}

The gross body-mass loss ( $\Delta m_{\mathrm{g}}$ ) of a person during a given time interval is the sum of the several components:

$\Delta m_{\mathrm{g}}=\Delta m_{\mathrm{sw}}+\Delta m_{\text {res }}+\Delta m_{0}+\Delta m_{\mathrm{wat}}+\Delta m_{\mathrm{sol}}+\Delta m_{\mathrm{clo}}$

Hence, total mass loss depends of sweat loss $\left(\Delta m_{\mathrm{sw}}\right)$, diference between carbon dioxide and oxigen $\left(\Delta m_{0}\right)$, evaporation of respiratory tract $\left(\Delta m_{\text {res }}\right)$, intake (food) and excretions (stools) of solids $\left(\Delta m_{\text {sol }}\right)$, intake and excretions (urine) of water $\left(\Delta m_{\text {wat }}\right)$, and sweat accumulation in the chlothing $\left(\Delta m_{\mathrm{clo}}\right)$. In the context of this study, only the sweat loss component $\left(\Delta m_{\text {sw }}\right)$ are considered and calculated as the rate of sweating $(S w R)$, from the difference between pre-test and posttest nude body weights (digital scale Chyo MW-100K). Values expressed to the body surface in the unit time (I $\mathrm{m}^{-2} \mathrm{~h}^{-1}$ ) [10]. 


\section{Subjective assessment of the level of comfort}

Thermal comfort is the condition of mind that expresses satisfaction with the thermal environment and is assessed by subjective evaluation. Subjective assessment of the level of comfort was rated by each subject using the McGinnis scale for ergometry testing in the climatic chamber [11]. This scale values range from 1 to 7, where 1 denotes "comfortable" and 7 denotes "extremely intolerable hot":

1) Comfortable

2) Warm but fairly comfortable

3) Uncomfortably warm

4) Hot

5) Very hot

6) Almost as hot as I can stand

7) So hot I am sick and nauseated.

The subjects were asked to point on the scale their subjective assessment every 5 min during the exposure.

\section{RESULTS AND DISCUSSION}

During EHST, not one test subjects showed any symptom of the heat stroke, or any disturbances related to serious types of heat illness. Tests lasted a maximum of $45 \mathrm{~min}$, with the only 2 recorded cases of early completion, due to subjective report of intolerable effort (RPE level 7). There were no cases of cancellation owing to achieving limitary values of tympanic temperature $\left(39^{\circ} \mathrm{C}\right)$ or heart rate $(190 \mathrm{bpm})$. Values of the main thermal strain indicators, measured in the last minute of exercises, are shown in Table 1.

In parallel with measuring of the thermal strain parameters, exercises on treadmill were discontinuously recorded by standard and thermal imaging camera (FLIR SC600 640×480 LWIR resolution and $0.03{ }^{\circ} \mathrm{C}$ sensitivity), every $5 \mathrm{~min}$. Footage analysis showed the efficiency of the vest cooling features, from start to the end of exercise, based on thermal imaging display of hot and cold zones on the vest and the torso area (Fig. 4).

Table 1. Comparison of the mean values $( \pm S D)$ for temperature and heart rate during tests; $45^{\text {th }} \mathrm{min}, 40{ }^{\circ} \mathrm{C}$

\begin{tabular}{lcc}
\hline Indicator & NoCOOL & ACOOL \\
\hline Tty & $37.73 \pm 0.18$ & $37.1 \pm 0.24$ \\
Tsk & $36.05 \pm 0.22$ & $35.6 \pm 0.16$ \\
HR & $142 \pm 14$ & $130 \pm 12$ \\
\hline
\end{tabular}

Comparable reviews of tympanic temperature values with a cooling system and without it are displayed in Fig. 5. The mean tympanic temperatures for the whole group without cooling varied from 36.39 to $37.73^{\circ} \mathrm{C}$, considered for the maximum exercise time 45 min. In case with cooling, around the $15^{\text {th }}$ min temperature began to grow noticeably slower, so in $35^{\text {th }} \mathrm{min}$ was lower by $0.57 \pm 0.08{ }^{\circ} \mathrm{C}$. Maximum diference of $0.69 \pm 0.07{ }^{\circ} \mathrm{C}$ was recorded at the end of EHST ( $p<$ $<0.05)$.

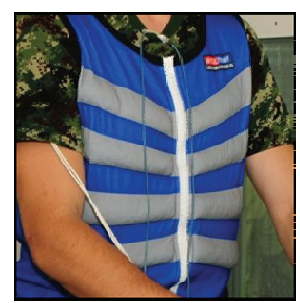

(a)

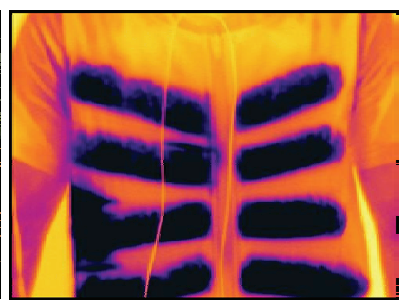

(b)
Figure 4. Snapshot vest recorded with standard (a) and thermal imaging camera (b), after 30 min of exercise.

\section{Body skin temperature}

Figure 6 presents the changes in $T_{\text {sk }}$ through the 45 min long heat-stress exposures, with a cooling system and without it.

Body skin temperature was increased in a similar

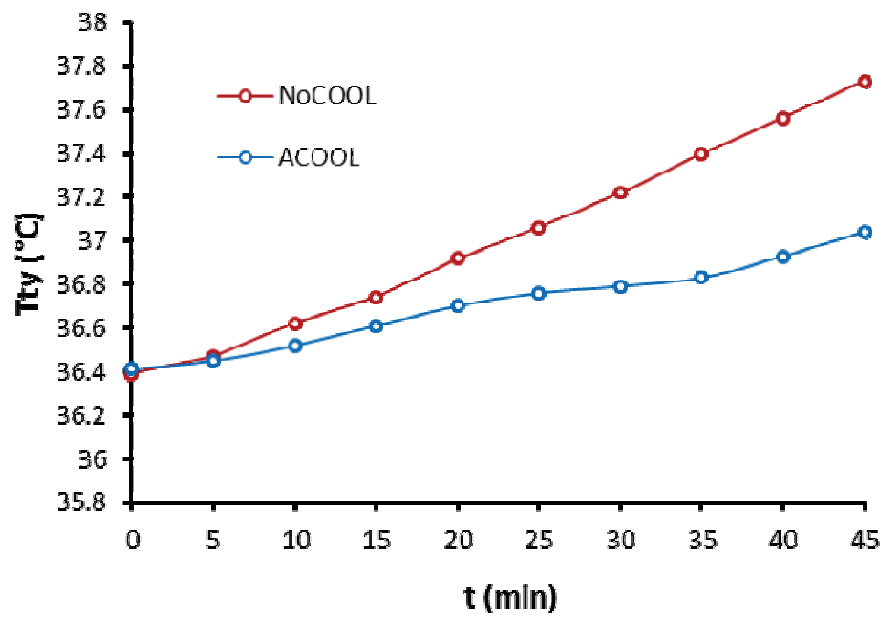

Figure 5. The mean tympanic temperature of all 10 subjects during $45 \mathrm{~min}$ without cooling (NOCOOL) and with cooling vest (ACOOL). 


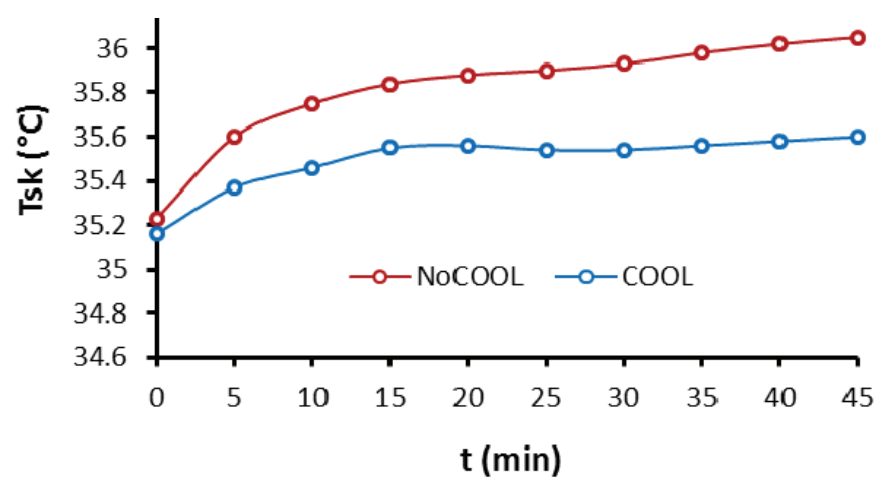

Figure 6. The mean body skin temperature of all 10 subjects during 45 min without cooling (NoCOOL) and with cooling vest (ACOOL).

way in all cases, much faster in the first $15 \mathrm{~min}$, then slowly. Maximum value of $T_{\text {sk }}$ was achieved in case NoCOOL in $45^{\text {th }} \min \left(36.05^{\circ} \mathrm{C}\right)$, while with cooling vest temperature was at the same time $35.6^{\circ} \mathrm{C}$.

At the two measuring points in the torso area (neck and scapula), significantly lower values of skin temperature were observed in relation to the option ACOOL (an average of $0.8 \pm 0.02{ }^{\circ} \mathrm{C}$ ), as a direct consequence of cooling vests effects. Measured values of $T_{\text {sk }}$ at the other two points (leg and arm) did not differ significantly, as expected $(p>0.05)$.

\section{Heart rate}

The average measured values of heart rate during laboratory tests are displayed in Fig. 7. No significant differences were observed in values of heart rate during tests. Heart rate in both cases (NoCOOL and ACOOL) increased in similar manner, but limit of 190 bpm was not reached during any single exercise. The heart rate, as an index of cardiovascular strain, was significantly reduced when cooling was provided during exposure to hot conditions. Maximum recorded heart rate was $142 \mathrm{bpm}$, without vest, in $45^{\text {th }} \mathrm{min}$. During EHST, in case ACOOL, heart rate was lower on average for $8 \mathrm{bpm}$ (maximum difference of $11 \mathrm{bpm}$ noted at the end of the EHST).

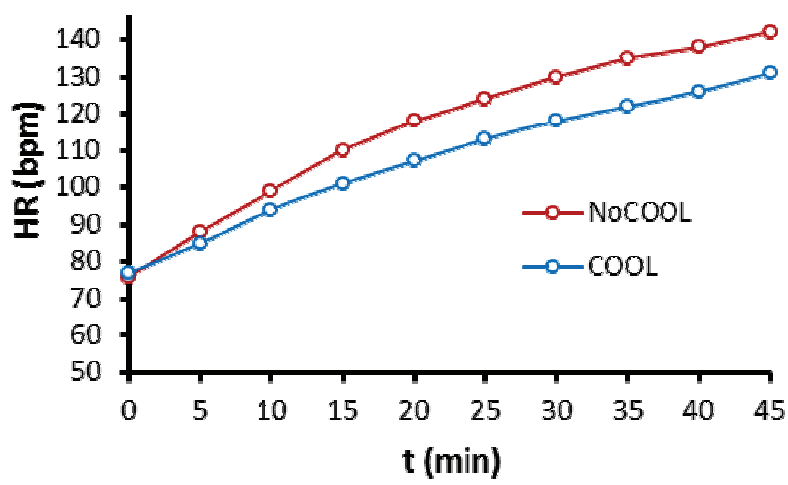

Figure 7. The heart rate of all 10 subjects during 45 min without cooling (NoCOOL) and with cooling vest (ACOOL).

\section{Sweat rate}

The average rate of sweating, as expected, achieved a higher value in NoCOOL case $\left(0.48 \pm 0.08 \mathrm{I} \mathrm{m}^{-2} \mathrm{~h}^{-1}\right)$, while using cooling system, value was significantly lower $\left(0.32 \pm 0.06 \mathrm{I} \mathrm{m}^{-2} \mathrm{~h}^{-1}\right)$.

\section{Subjective assessment of comfort}

From the $5^{\text {th }}$ to $45^{\text {th }}$ min participants expressed 1-2 levels better feeling of comfort wearing cooling vest, then in cases without it. Subjective assessments of the level of comfort during exercises, with cooling vest and without it, are showed in Fig. 8.

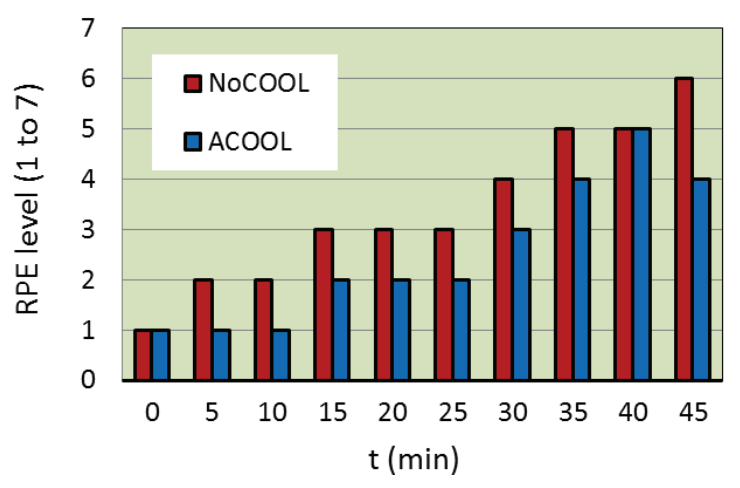

Figure 8. Comparison of the subjective assessment of the level of comfort of all 10 subjects with the cooling system (ACOOL) and without it (NoCOOL).

As the greatest benefit of all cooling systems subjects cited easier breathing and less strain compared to tests without cooling, which is confirmed by the measured lower values of heart rate.

Sweating as a mechanism for disclosure of excess heat has a special importance in the thermal stress caused by physical activity, when it occurs not only as a consequence of thermal factors (increasing of body core and skin temperature), but also non-thermal factors such as central activation, activation of musclemechano receptors metabolism and activation of baroreflex due to physical activity. According to test results, the rate of sweating is lower when using the body cooling systems average by $0.16 \mathrm{I} \mathrm{m}^{-2} \mathrm{~h}^{-1}(p<0.001)$. 
Because exercises are not lasting equaly long with all subjects, the rate of sweating we expressed per hour.

Our results are consistent with the study of Hadid and Yanovich [6], who carried out the investigation related to effects of the cooling system based on air circulation to the thermal stress caused by physical effort in test subjects.

McLellan [14] obtained similar results exploring the efficacy of an air-cooling vest to reduce thermal strain for light armour vehicle (LAV) personnel. In this study, seven males were exposed to either hot dry - HD (49 $\left.{ }^{\circ} \mathrm{C}, 10 \% \mathrm{RH}\right)$ or warm, humid - WH $\left(35^{\circ} \mathrm{C}, 70 \% \mathrm{RH}\right)$ conditions while either receiving (C) or not receiving (NC) cooling through an air-vest. All subjects completed the $3 \mathrm{~h}$ of heat-stress exposure during all conditions but the rise in rectal temperature approached $2{ }^{\circ} \mathrm{C}$ during HD with NC. When cooling was provided the rise in rectal temperature was minimal throughout the heat stress. It was concluded that micro-climate conditioning was an effective way to reduce the thermal strain of LAV crew.

\section{CONCLUSION}

Methodology used in this study and experimental protocols were carried out in accordance with contemporary standards in area of thermal strain evaluation by physiological measurements (ISO 9886), with respect to prescribed measures of medical supervision of subjects exposed to extreme hot environment (ISO 12894). All laboratory tests were conducted using high performance equipment (Biopac, Quinton ${ }^{\circledR}$ ), with technical features that enable to measure, monitor and record necessary physiological parameters in real time. Among other things, validity of results confirming engagement of sufficient number of test subjects (volunteers) with similar anthropometric parameters, selected according to strict criteria from a larger number of potential participants.

The evaluation of the cooling system in this study found two important conclusions: in case of wearing cooling vest covering torso area, body core temperature (measured through tympanic temperature) grows slower, and mean body skin temperature is significantly lower. Moreover, heart rate values and subjective assessment of comfort levels point to the much expressed test subjects physiological stability, which is very important result from the aspect of confidence and efficiency in fulfilling the given professional activities.

The results of this study have clearly identified the benefits of a liquid circulation cooling vest in lowering the thermal strain for the mounted test subjects. Tym- panic temperature, as an index of thermal strain, and heart rate, as an index of cardiovascular strain, were reduced when cooling was provided during exposure to hot conditions.

\section{Acknowledgements}

Ministry of Education, Science and Technological Development of the Republic of Serbia supported this work, Grant No. TR34034 (2011-2015).

\section{REFERENCES}

[1] D. Moran, A. Shitzer, K. Pandolf, A physiological strain index to evaluate heat stress, Am. J. Physiol. 275 (1998) 129-134.

[2] W. Kenney, Heat flux and storage in hot environments, Int. J. Sports. Med. 19 (1998) S92-S95.

[3] I. Mekjavic, E. Banister, J. Morrison, Environmental Ergonomics, Taylor \& Francis, London, 1987.

[4] G. Donaldson, W. Keatinge, R. Saunders, Cardiovascular responces to heat stress and their adverse consequences in healthy and vulnerable human populations, Int. J. Hypertermia 19 (2003) 225-235.

[5] C. Cian, P. Barraud, B. Melin, C. Raphael, Effects of fluid ingestion on cognitive function after heat stress or exercise-induced dehydration, Int. J. Psychophysiol. 42 (2001) 243-251.

[6] A. Hadid, R. Yanovich, T. Erlich, G. Khomenok, D. Moran, Effect of a personal ambient ventilation system on physiological strain during heat stress wearing a ballistic vest, Eur. J. Appl. Physiol. 104 (2008) 311-319.

[7] S. Montain, M. Sawka, B. Cadarette, M. Quigley, J. McKay, Physiological tolerance to uncompensable heat sress: effects of exercise intensity, protective clothing, and climate. J. Appl. Physiol. 77 (1994) 216-222.

[8] W. Teal, Microclimate cooling, in Proceedings of Chemical biological individual protection conference, March 7-9, 2006, US Army Natick Solder Center, MA, USA, 2006.

[9] ISO 12894 (E): Ergonomics of the thermal environment Medical supervision of individuals exposed to extreme hot or cold environment, 2008.

[10] ISO 9886: Ergonomics - evaluation of thermal strain by psychological measurements, 2008.

[11] N. McGinnis, Ergometry testing in the climatic chamber, Sports Med. 25 (1999) 86-89.

[12] MP SYSTEM Hardware Guide, Biopac Systems Inc., pp. 2-10, 26-29, 120-124.

[13] Acq Knowledge ${ }^{\circledR} 4$ Software Guide, Biopac Systems Inc., www.biopac.com

[14] T. McLellan, The efficacy of an air-cooling vest to reduce thermal strain for light armour vehicle personnel, Technical report, DRDC Toronto, TR 2007-002, 2007. 


\section{IZVOD}

\section{Uticaj prsluka za hlađenje sa sistemom pasivnog isparavanja na nivo fiziološkog opterećenja radnika hemijske} industrije u toploj sredini

Radovan M. Karkalić ${ }^{1}$, Dalibor B. Jovanović ${ }^{2}$, Sonja S. Radakovic ${ }^{3}$, Dušan S. Rajić ${ }^{4}$ Biljana V. Petrović ${ }^{5}$, Negovan D. Ivanković ${ }^{1}$, Željko B. Senić

${ }^{1}$ Univerzitet odbrane, Vojna akademija, Beograd, Srbija

${ }^{2}$ Tehnički opitni centar, Generalštab Vojske Srbije, Beograd, Srbija

${ }^{3}$ Medicinski fakultet Vojnomedicinske akademije, Univerzitet odbrane, Beograd, Srbija

${ }^{4}$ Univerzitet u Beogradu, Inovacioni centar Tehnološko-metalurškog fakulteta, Beograd, Srbija

${ }^{5}$ Prirodno-matematički fakultet, Univerzitet u Kragujevcu, Srbija

${ }^{6}$ Vojnotehnički institut, Beograd, Srbija

\section{(Stručni rad)}

Rad predstavlja rezultate naučnih istraživanja na polju efikasnosti sistema za hlađenje tela iz grupe pasivnih sistema na bazi isparavanja i njegov uticaj na fiziološku podobnost ljudi u uslovima izloženosti fizičkom naporu i ekstremno visokim temperaturama. Podaci i dobijeni rezultati zasnovani su na ispitivanjima sprovedenim u klimatskoj komori Instituta za higijenu VMA u Beogradu. Deset ispitanika muškog pola dobrovoljno je podvrgnuto testovima toplotnog opterećenja usled fizičkog napora, izazvanog hodanjem na pokretnoj traci sa brzinom hoda od $5 \mathrm{~km} / \mathrm{h}$, u toploj sredini (temperatura vazduha $40{ }^{\circ} \mathrm{C}$ ). Testovi su realizovani sa ispitanicima srednjih godina (27.2 \pm 2.6$)$, sličnih antropometrijskih parametara $(74 \pm 7 \mathrm{~kg}, 184 \pm 9 \mathrm{~cm})$, u varijanti nošenja radne odeće bez ikakvog rashladnog sistema (opcija NoCOOL) i uz upotrebu rashladnih prsluka za hlađenje tela, model Arctic Heat ${ }^{\circledast}$ (opcija ACOOL). Kao pokazatelji fiziološkog opterećenja određivane su: srednja temperatura kože $\left(T_{\text {sk }}\right)$, timpanična temperatura $\left(T_{\text {ty }}\right)$ i frekvencija srčanog rada $(H R)$, dok je intenzitet znojenja $(S W R)$ izračunat kao pokazatelj vodeno-elektrolitskog statusa. U svim slučajevima izlaganje fizičkom naporu u toploj sredini indukovalo je fiziološki odgovor, manifestovan kroz povećanje timpanične temperature, frekvencije srčanog rada i intenziteta znojenja. $U$ varijantama primene rashladnog prsluka (COOL), timpanična temperatura i srednja temperatura kože su imale značajno niže vrednosti $(p<0,05)$, kao i intenzitet znojenja $(p<0,001)$. Eksperimentalni rezultati dokazali su uticaj rashladnog prsluka, korišćenog preko radne odeće, na snižavanje nivoa fiziološkog opterećenja tokom izlaganja korisnika ekstremnim uslovima, u poređenju sa identičnim testovima u varijanti bez hlađenja tela.
Ključne reči: Hemijska industrija • Toplotni stres • Rashladni prsluk • Radna odeća • Fiziologija napora 